\section{Insecticide Resistance}

Of A. quadrimaculatus

In Bolivar County, Miss.

By Willis Mathis, B.S., H. F. Schoof, Ph.D., Kenneth D. Quarterman, B.S., M.P.H., and RichaRd W. FAY, Ph.D

The data represent the first detection of resistance in Anopheles quadrimaculatus to chlorinated hydrocarbon insecticides and initial establishment of anopheline resistance to dieldrin.

$\mathrm{D}$ ESPITE the widespread use of DDT residual applications for the eradication of malaria in the southeastern United States during the period 1946 to 1950 , there has been no indication that Anopheles quadrimaculatus (Say) has developed resistance to this compound. Kruse and associates (1) reported that $A$. quadrimaculatus became less susceptible to larvicidal treatments of DDT in the Tennessee Valley Authority malaria control program, but later studies (2) indicated that factors other than resistance were responsible for the apparent lack of effectiveness of the control operations.

However, field studies in Bolivar County, Miss., now demonstrate that, while $A$. quadrimaculatus in that area is still susceptible to DDT, it is highly resistant to dieldrin, $\mathrm{BHC}$, and chlordane.

The authors are all with the Communicable Disease Center of the Public Health Service. They are stationed in Savannah, Ga., with the Technical Development Laboratories where Mr. Quarterman is chief. Mr. Mathis and Dr. Fay are entomologists, and Dr. Schoof is chief of the Biology Section.
The first indication of resistance in this species was noted in field tests, employing the method of Fay and associates (3). In these tests an average 24-hour mortality of 15 percent was obtained when 62 adult mosquitoes ( 3 replicate tests) were exposed to paper treated by immersion in a 0.25 percent dieldrin-xylene solution.

To substantiate this apparent loss of susceptibility to dieldrin, further tests were conducted with paper treated by immersion in 0.25 percent and in 1.0 percent dieldrin solutions. DDTtreated surfaces also were assayed. The female mosquitoes used were collected from natural resting places at five widely separated locations in Bolivar County during June and July 1955 and held overnight with food and water before their exposure to chemical residues. The results of these tests clearly indicated that $A$. quadrimaculatus was highly resistant to dieldrin residues although quite susceptible to deposits of DDT (table 1).

Since the dosage of the toxicants per square foot was unknown in the foregoing tests, additional tests were run using the technique of Fay and associates (4) in which plywood panels were treated with known dosages of the toxicant. Four chemicals were evaluated: DDT at $200 \mathrm{mg} . / \mathrm{sq}$. ft., dieldrin at $25,50,100$, and $200 \mathrm{mg} . / \mathrm{sq}$. ft., BHC at $50 \mathrm{mg} . / \mathrm{sq}$. ft., and chlordane at $100 \mathrm{mg} . / \mathrm{sq}$. ft. The exposure period was 30 minutes, except for the DDT tests in which $30-, 60-$, and 120 -minute periods were employed.

To compare the susceptibility of the Bolivar County A. quadrimaculatus with that of nonresistant $A$. quadrimaculatus, parallel tests were conducted at the Public Health Service Technical Development Laboratories, Savannah, Ga., with a laboratory-reared strain (TDL). The adult mosquitoes of the 'TDL strain were processed in the same manner as the Bolivar County adults. The plywood panels used in the tests were sprayed in quadruplicate sets at Savannah. After the treatment, two sets of panels of each dosage were tested at Savannah against the laboratory strain. Two sets of panels (one 
Table 1. Percentage mortality in 24 hours of female Anopheles quadrimaculatus exposed for 45 minutes to dieldrin and DDT residues

\begin{tabular}{l|r|r|r}
\hline \multicolumn{1}{c|}{ Treatment } & $\begin{array}{c}\text { Number } \\
\text { of rep- } \\
\text { licates }\end{array}$ & $\begin{array}{c}\text { Total } \\
\text { females }\end{array}$ & $\begin{array}{c}\text { Adjusted } \\
\text { 24-hour } \\
\text { mortality 1 } \\
\text { (percent) }\end{array}$ \\
\hline & & & \\
\hline Dieldrin, 0.25 percent_- & 38 & 787 & 18 \\
Dieldrin, 1 percent_. & 4 & 79 & 6 \\
DDT, 1 percent_.... & 38 & 821 & 96 \\
Check.... & 15 & 341 & 3 \\
\hline
\end{tabular}

1 Based on Abbotts formula.

tested, one untested) were then forwarded to Mississippi. A similar pair of panels was retained at Savannah.

From the results of the panel tests with residues aged 1 to 13 days, it is readily apparent that the Bolivar County strain is highly resistant to dieldrin (table 2). Deposits of 100 and 200 milligrams per square foot produced average mortalities of 5 percent or less for this strain, compared with the 98 percent mortality achieved for the TDL strain with 25 milligrams of dieldrin per square foot. The data likewise show that the Bolivar County strain has little susceptibility to BHC and chlordane at the dosages normally used for residual applications.
Although the 30-minute exposure to DDT resulted in low mortalities for both strains, these low rates are considered to reflect the length of the exposure period rather than resistance to the pesticide. In 1948, tests with the TDL strain at 30-minute exposures to 200 milligrams of DDT per square foot produced average mortalities of 44 percent (4). In the present tests with the Bolivar County strain, the mortality rates were 51 and 85 percent, respectively, following 60-minute and 120-minute exposures to replicate panels, each sprayed with 200 milligrams of DDT per square foot. Moreover, exposure to paper treated with 1-percent DDT produced an average mortality of 96 percent for the Bolivar County strain (table 1).

The development of resistance in this species to dieldrin, chlordane, and BHC apparently is due to the extensive use of these pesticides in agriculture and for the control of malaria mosquitoes. Bolivar County is largely agricultural with cotton the chief crop. Insect control on cotton requires repeated insecticidal applications, many of which are made by airplane dust. ing. According to the Bolivar County agricultural agent and the local pesticide companies, the insecticides used in 1955 in the order of the quantities dispersed were dieldrin, toxaphene,

Table 2. Percentage mortality in $\mathbf{2 4}$ hours of adult Anopheles quadrimaculatus from Bolivar County, Miss., and those of a laboratory strain exposed for 30 minutes to insecticidal deposits on plywood panels

\begin{tabular}{|c|c|c|c|c|c|}
\hline Pesticide & $\mathrm{Mg} . / \mathrm{sq} . \mathrm{ft}$. & Strain & Replicates & $\begin{array}{c}\text { Total } \\
\text { females }\end{array}$ & $\begin{array}{l}\text { Mortality } \\
\text { (percent) }\end{array}$ \\
\hline \multirow{3}{*}{ Dieldrin . . } & $(25 \ldots \ldots \ldots$ & $\left\{\begin{array}{l}\text { Bolivar County } \\
\text { TDL }\end{array}\right.$ & $\begin{array}{l}1 \\
4\end{array}$ & $\begin{array}{r}25 \\
258\end{array}$ & $\begin{array}{r}8 \\
98\end{array}$ \\
\hline & 100 & $\left\{\begin{array}{l}\text { Bolivar County } \\
\text { TDL }\end{array}\right.$ & $\begin{array}{l}1 \\
4\end{array}$ & $\begin{array}{r}23 \\
229\end{array}$ & $\begin{array}{r}5 \\
100\end{array}$ \\
\hline & 200 & $\left\{\begin{array}{l}\text { Bolivar County } \\
\text { TDL }\end{array}\right.$ & $\begin{array}{r}20 \\
4\end{array}$ & $\begin{array}{l}496 \\
233\end{array}$ & $\begin{array}{r}0 \\
100\end{array}$ \\
\hline BHC (36 percent gamma isomer) $\ldots$ & 50 & $\left\{\begin{array}{l}\text { Bolivar County } \ldots \\
\text { TDL }\end{array}\right.$ & $\begin{array}{r}10 \\
4\end{array}$ & $\begin{array}{l}244 \\
213\end{array}$ & $\begin{array}{r}3 \\
167\end{array}$ \\
\hline Chlordane & 100 & $\left\{\begin{array}{l}\text { Bolivar County } \ldots \\
\text { TDL }\end{array}\right.$ & $\begin{array}{r}10 \\
4\end{array}$ & $\begin{array}{l}248 \\
205\end{array}$ & $\begin{array}{r}5 \\
24\end{array}$ \\
\hline $\mathrm{DDT}_{\ldots}$ & $200 \ldots$ & $\left\{\begin{array}{l}\text { Bolivar County } \\
\text { TDL }\end{array}\right.$ & $\begin{array}{r}20 \\
4\end{array}$ & $\begin{array}{l}485 \\
223\end{array}$ & $\begin{array}{l}353 \\
450\end{array}$ \\
\hline
\end{tabular}

1 In one test the mortality was only 13 percent; in the remaining three it was $94,100,100$.

2 1-day-old residues (2 replicates) gave 87 percent mortality.

3 Mortality for individual tests ranged from 13 to 95 percent.

4 1-day-old residues gave a mortality of 25 percent; 13-day-old residues, a mortality of 83 percent. 
endrin, DDT plus BHC, DDT, and aldrin. DDT generally is not used until August, whereas the other pesticides are employed as early as June. Presumably, the airplane and ground dusting techniques employed provide ample opportunity for treating both the larval and adult stages of the mosquito. In addition, Bolivar County has conducted a residual spray program for malaria control in rural areas since 1944. DDT and DDT-chlordane formulations have been used in this program, the latter since 1950.

The level of susceptibility to dieldrin was suggested in 1953, in Mississippi, when heavy dosage of this chemical ( 0.5 to $1 \mathrm{lb}$./acre) failed to provide control of anopheline larvae in rice fields (5) even though similar applications in landlocked ponds near Savannah, Ga., had been satisfactory (6). In the Savannah tests, however, the general mosquito population was only slightly affected by the test applications, whereas in Mississippi the dust treatment of cotton exposed both the adult and larval stages of the mosquitoes to the insecticides over considerable areas.

An attempt is now in progress to colonize the
Bolivar County strain so that it will be available for bioassay purposes.

\section{REFERENCES}

(1) Kruse, C. F., Hawkins, W. B., and Ludvik, G. F.: Resistance of Anopheles quadrimaculatus to DDT in the Tennessee Valley. J. Econ. Ent. $45: 810$ (1952).

(2) Hawkins, W. B., and Hall, T. F.: The present status of resistance to DDT of Anopheles quadrimaculatus in the Tennessee Valley (abstract). In Second Annual Meeting of the Entomological Society of America. Washington, D. C., 1954, p. 40.

(3) Fay, R. W., Kilpatrick, J. W., Crowell, R. L., and Quarterman, K. D.: A method for field detection of adult-mosquito resistance to DDT residues. Bull. World Health Org. 9: 345 (1953).

(4) Fay, R. W., Baker, W. C., and Grainger, M. M.: Laboratory studies on the resistance of Anopheles quadrimaculatus to DDT and other insecticides. J. Nat. Malaria Soc. 8:137 (1949).

(5) Mathis, W., Pickett, V. B., and Miller, W. O.: Chemical control of rice field mosquitoes in Mississippi. Pub. Health Rep. 69: 803-807 (1954).

(6) Mathis, W., and Quarterman, K. D.: Field investigations on the use of several chlorinated hydrocarbons as mosquito larvicides. Am. J. Trop. Med. \& Hyg. 2:318-324 (1953).

\section{Army Posts Fluoridate Water Supplies}

There are 21 Army posts in the United States, Alaska, Hawaii, and Puerto Rico which now fluoridate their water supplies, according to recent information made available by the Army Surgeon General.

Requests for fluoridation are submitted to the Surgeon General and are accompanied by a report on the natural fluoride content of the water on the post and a statement of the number of persons to benefit from the procedure.

The age of the population at an installation is one of the criteria for determining the priority for setting up the fluoridation process. A census must be taken of the number of persons under 12 years of age, the number between 12 and 16, and those between 16 and 20 years living on the installation and reported with the application for fluoridation.

The Committee on Dentistry of the National Research Council has supported fluoridation of water supply for use on military posts whenever feasible and especially where there is a child population in residence. The Army Medical Service approved the fluoridation of drinking water at Army installations in July 1954. 